Cinémas

Revue d'études cinématographiques

Journal of Film Studies

\title{
Ouvrages reçus / Books Received
}

Volume 4, numéro 3, printemps 1994

URI : https://id.erudit.org/iderudit/1001046ar

DOI : https://doi.org/10.7202/1001046ar

Aller au sommaire du numéro

Éditeur(s)

Cinémas

ISSN

1181-6945 (imprimé)

1705-6500 (numérique)

Découvrir la revue

Citer ce document

(1994). Ouvrages reçus / Books Received. Cinémas, 4(3), 183-183.

https://doi.org/10.7202/1001046ar d'utilisation que vous pouvez consulter en ligne.

https://apropos.erudit.org/fr/usagers/politique-dutilisation/ 


\section{Ouvrages reçus / Books Received}

Bulletin of Francophone Africa, $\mathrm{n}^{\circ} 3$ (Spring 1993) $106 \mathrm{p}$.

CARRIÈRE, Louise. Les Relations cinématographiques FranceQuébec. Montréal: Centre de recherche cinéma/ réception de l'Université de Montréal et Cinémathèque québécoise/Musée du cinéma, 1994, $183 \mathrm{p}$.

DION, Marie-Josée, ROCHON, François (direction). «Idiologies ou Abrégé de bêtise contemporaine ", Dires, vol. 11, n 2 (automne 1993) $152 \mathrm{p}$.

LA ROCHELLE, Réal. Cinéma en rouge et noir. 30 ans de critique de cinéma au Québec. Montréal: Triptyque, 1994, $284 \mathrm{p}$.

MARION, Philippe. Traces en cases. Travail graphique, figuration narrative et participation du lecteur. Essai sur la bande dessinée. Louvain-la-Neuve: Academia, 1993, 313 p.

MOURGUES, Nicole de. Le Générique de film. Paris: Méridiens Klincksieck, 1994, 292 p.

Plans de caméra. Montréal: SRC/Éditions Saint-Martin, 1993, $92 \mathrm{p}$. 